\title{
16. \\ POETIKA UMETNIČKE PROZE \\ VLADANA DESNICE
}

\section{Nikolina Konjević Milošević}

UDK: 821.163.42-3Desnica. V.

Stručni članak

Sažetak: Književni opus Vladana Desnice u celini je oslobođen pripadnosti određenom književnom izrazu i stvaralačkom modelu, književnom pokretu i pravcu. U stvaranju svojih umetničkih tvorevina ovaj pisac je prevashodno bio usmeren na ostvarivanje estetske vrednosti književnog dela koja, prema njegovom mišljenju, predstavlja primarnu umetničku vrednost. U težnji da u prvi plan istakne i prikaže čoveka u njegovoj različitosti, Desnica se zalagao za iskrenost kao jedan od glavnih poetičkih principa. Složenu problematiku čovekovog života Desnica je oslikavao kroz postupke i razmišljanja svojih junaka. Iako su Desničini likovi pripadali različitim društvenim slojevima i profesijama, sve ih je na kraju obuzimala šutnja i obamrlost nakon različitih životnih iskustava. Poetski stavovi Vladana Desnice izloženi u esejima, pripovetkama i romanima ukazuju da je najveću pažnju poklanjao čoveku i njegovom unutrašnjem svetu.

Ključne reči: Vladan Desnica, poetika, umetnička proza, estetska vrednost, doživljaj, integralni realizam

$\sqrt{7}$

ladan Desnica je pisac raznovrsnog i obimnog dela, gotovo svih rodova književnog stvaralaštva. Kulturnu i književnu delatnost ostvarivao je na različite načine, posmatrajući i zapisujući sve što je u životu i kulturi smatrao značajnim i vrednim literarne pažnje. Da bismo se u potpunosti približili njegovom književnom delu i otkrili Desničinu „tajnu stvaranja“, neophodno je čitati ga i sagledavati u celini, kroz sva njegova pisana ostvarenja. Takav je pristup zagovarao i Vojislav Nikčević, naglašavajući da je Desnica „prevashodno radio kao zatočenik riječi“ i da je „u svojim djelima, pismima i razgovorima s drugim piscima, kao i u posebnim zapisima, ostavio niz obavještenja o problemima umjetničkog stvaranja". ${ }^{1}$

Svoju eksplicitnu poetiku Desnica je razvijao u svojoj esejistici, kao i u većini teorijskih tekstova, primenjujući je na svoje pripovetke i romane. Upoznavši njegov celokupan opus, ne zanemarivši niti jedan njegov segmenat, možemo stvoriti sliku njegove stvaralačke poetike. Nemoguće je u potpunosti razumeti delo Vladana Desnice, a prethodno ne proučiti

1 Vojislav NiKČEvić, „Poetika Vladana Desnice“, Izraz, 13/1969., br. 7, 53. 
njegove eseje, kritike i poglede. Oni sadrže sažeto prikazanu poetiku i životnu filozofiju pisca i predstavljaju putokaz u razumevanju njegovog životnog i stvaralačkog opredeljenja.

Elementi Desničine poetike najvidljiviji su u romanu Proljeća Ivana Galeba, te u narednim esejima: „Zapisi o umjetnosti“, „Riječ na vrhu jezika“, „Primijenjena umjetnost“, „B. Kroče i zbrka oko njega“, „Jedan zakašnjeli prilog diskusiji o tipičnome“, „Razgovor na Književnom petku“, „O jednom gradu i jednoj knjizi“, „Djelo i kritika“, „Ličnost i prosede“, „Dva kratka eseja: 'Marginalije o iracionalnom' i 'Zloupotreba jednog termina: detalj'“, „Tri zapisa o umjetnosti: 'O realizmu', 'Intencionalnost u umjetnosti' i 'Hotimično iskustvo"“.

Mnogi pogledi na umetnost i književnost, kao i pitanja vezana za njegovo književno delo, nalaze se u razgovorima i intervjuima koje je Desnica vodio u periodu 1952-1966. Među pomenutima možemo izdvojiti: Desničino pismo upućeno Aleksandru Tišmi od 23. marta 1952, razgovor vođen sa Grozdanom Olujić pod naslovom „Pjesnik tuge i nade“,2 razgovor sa Vlatkom Pavletićem „Svako djelo vrijedi tačno onoliko koliko poetskog sadrži u sebi... “3 i „Razgovor s Vladanom Desnicom o umjetničkom stvaranju“ vođen sa Jevtom Milovićem. ${ }^{4}$

Kraći razgovori i intervjui nalaze se u IV knjizi Desničinih Sabranih djela: „Tri pitanja Vladanu Desnici“ (1960), „Razgovor na Radio-Beogradu“ (1961), „Između muzike i literature“ (1961), „Bliže upoznavanje s nizom konkretnih vidova stvarnosti liječi nas od apstraktnosti“ (1963), „Djelo nastaje dalje od pisaćeg stola“ (1963) i „Prvu novelu namenio sam Politici“ (1966).

Desničino celokupno delo karakterišu autorski komentari koji treba da približe i objasne određeni pojam, bez obzira da li se on odnosi na teoriju ili na stvaralačku praksu. Desnica nije postavljao stroge granice između teorijske i stvaralačke prakse, nego ih je posmatrao kao delove jedinstvenog procesa u stvaranju umetničke tvorevine. Književne rodove, vrste i žanrove doživljavao je kao jednako vredne, smatrajući da se međusobno razlikuju samo po stepenu kreativnosti. Njegov književni izraz je nužno čitati u kontekstu određenog književnog žanra. On poseduje izvesnu širinu koju ovaj pisac ima podjednako i kao čovek i kao stvaralac. Osnovu svog širokog obrazovanja Desnica je stekao zahvaljujući bogatoj porodičnoj tradiciji, sklonosti prema umetnosti i književnosti, klasičnom gimnazijskom obrazovanju, studijama prava i filozofije u Zagrebu i Parizu, putovanjima po Italiji i Francuskoj, te neprestanoj težnji za otkrivanjem najdubljih slojeva ljudske misli.

Poznavao je više stranih jezika: latinski, grčki, francuski, italijanski, ruski i španski, što mu je omogućavalo bolje i potpunije upoznavanje dela iz svetske književnosti. Do izvorišta svoje poetike Desnica je mogao doći i vlastitim prevođenjima. U IV knjizi njegovih $S a-$ branih djela navedeno je 39 bibliografskih jedinica Desničinih prevoda sa francuskog, italijanskog i ruskog jezika. Među njima poseban značaj imaju prevodi Kročeovih teorijskih tekstova, koji su izvršili značajan uticaj na formiranje njegovih poetičkih stavova. Već 1938.

\footnotetext{
Grozdana Olujić, Pisci o sebi, Beograd 1959.

Vlatko Pavletić, Trenutak sadašnjosti, Zagreb 1960.

4 Jevto Milović, Razgovor sa umjetnicima, Beograd 1983.
} 
u Desničinom prevodu izlaze Kročeovi Eseji iz estetike, a 1969. Desničin izbor i prevod 29 Kročeovih eseja i studija pod nazivom Književna kritika kao filozofija. Radomir V. Ivanović kaže: „Izborom djela (koje je prevodio) Desnica je pokazao izvore 'idejne filijacije', koja podrazumijeva istovremeno nadahnjivanje i kreativnog i estetskog duha".5

Sa podjednakim interesovanjem čitao je domaće i strane pisce, posebno antičke, francuske, italijanske i ruske. Od domaćih pisaca naročito je čitao i cenio Lazu K. Lazarevića kao pripovedača, zatim Lazu Kostića, Milovana Glišića, Ivu Andrića, Dositeja i Njegoša. O Matavulju je napisao fragmente eseja koji nije uspio da završi, kao i skicu filmskog scenarija o Dositeju pod naslovom „Vječiti putnik“, koja takođe ostaje nedovršena. Voleo je prozu Ive Ćipika, kao i novele Dinka Šimunovića.

U njegovom književnom delu, u njegovoj ličnosti, kao i u zavičaju iz kojeg je potekao, spajali su se slovenski i romanski uticaji. Pod slovenskim uticajem podrazumeva se Desničino poznavanje i sklonost ka ruskoj književnosti. Od ruskih pisaca čitao je Puškina, Gogolja, Bunjina, Turgenjeva, Gončarova. Tolstoja je doživljavao ne samo kao pisca, već i kao jednog od najvećih mislilaca novijeg vremena. Desnica je preveo njegove pripovetke „Poslije plesa“ i „Luzern“.

U Tolstojevom književnom stvaralaštvu nalazio je potvrdu za jednu od osnovnih teza svoje poetike, da je osnovni i krajnji smisao svih čovekovih aktivnosti borba protiv smrti. Iz njega je Desnica došao do sopstvenog doživljaja smrti kao glavnog pokretača svih ljudskih postupaka i aktivnosti.

Govoreći o uticaju romanske književnosti na Desnicu, treba naglasiti da posebno mesto zauzimaju francuski i italijanski pisci. Mnogo je čitao Balzaka, Stendala i Flobera, navodeći ih u svojim teorijskim tekstovima kao primer dobrih pisaca i stilista. Desnica je čitao francuske pisce realiste, koji realizam istovremeno i prevazilaze. Tako je čitao i Prusta, koji se svojom prozom udaljavao od poetike realizma, prelazeći sa opisa spoljašnje stvarnosti na prikaz njenog odraza u čovekovom unutrašnjem svetu.

Sa navedenim autorima Desnica je vodio neku vrstu dijaloga koji danas možemo pratiti na intertekstualnom nivou. Pomenuti dijalozi dati su implicitno u Desničinoj prozi kroz podudarnost ideja ili sličnost nekih tema i kroz osobine nekih likova te otkrivaju izvesne duhovne srodnosti sa navedenim autorima. Od italijanskih pisaca naročito je voleo Dantea, o kojem je skicirao nedovršeni esej.

Desnica je čitao i dela drugih evropskih književnosti, npr. nemačke, ali na njegov duhovni razvoj i književni ukus najveći uticaj su izvršile francuska, talijanska i ruska književnost. U gimnazijskim danima je upoznao antičke pisce. Naročito je cenio Eshilovog Okovanog Prometeja, o čemu nam svedoči i roman Proljeća Ivana Galeba.

Posmatrajući iz današnje vremenske perspektive navedene odrednice koje karakterišu Vladana Desnicu i kao čoveka i kao stvaraoca, uočavamo da je po mnogo čemu bio ispred svoga vremena. U svojim proznim delima Desnica je ostvario povezanost između dve najvažnije osobine moderne proze 20 . veka, njene poetske i intelektualno-esejističke orijentacije. Pomenute osobine predstavljaju prirodni izraz Desničine stvaralačke ličnosti.

5 Radomir V. Ivanović, Po sunčanom satu, Novi Sad 2001., 92. 
U navedenom stvaralačkom kontekstu Vladan Desnica je stvorio književno delo koje se nameće kao samostalna i jedinstvena estetska i književna vrednost. Pored svekolikog znanja koje je posedovao, Desnica je iznad svega bio artist. U stvaranju svojih umetničkih tvorevina bio je prevashodno usmeren na ostvarivanje estetske vrednosti književnog dela koja, prema njegovom mišljenju, predstavlja primarnu umetničku vrednost.

Iako je akcenat prevashodno stavljao na sadržinu, uočavamo da je mnogo pažnje poklanjao formalnom savršenstvu teksta i rečeničnom ritmu, što je vidljivo u njegovom neprestanom „navraćanju“6 svakoj ispisanoj rečenici pre konačne redakcije: „Ja prozu moju čitam glasno po trideset puta, najobičnije rečenice, recimo, da tako kažem, i činim da mi drugi čitaju, da mi čitaju iz druge sobe. I tako to se pročita iks puta glasno."

Izvor Desničine neprestane brige za ritam rečenice nalazi se u pradavnini, kada je književnost bila usmena, kada je književno delo moralo biti lepo i savršeno kada ga se slušalo. Desnica je smatrao da se potpuna recepcija dela ostvaruje postizanjem apsolutne literarnosti svakog strukturnog elementa:

Salije se neko djelo pa se onda svaka pojedina tačka, svako pojedino poglavlje, svaka stranica prorađuje iznova i uzima se nekako u razmatranje, u rad, pod lupu, (...) kao da je to centralno, najvažnije mjesto u čitavoj knjizi, pa za njim dolazi drugo, pa treće, tako da je svaka stranica jedanput bila u položaju te najvažnije, te glavne stranice, pa je tako sa zdušnošću, i minucioznošću, i prilježnošću rođena. ${ }^{8}$

Desnica je bio „nepovjerljiv prema plodnim nadahnućima“ i nije verovao u sretne momente stvaranja u kojima čovek nadmašuje samoga sebe. Smatrao je da je „svako pravo umjetničko oblikovanje u svojoj biti složen i duboko smiren proces (...) jedno teoretsko

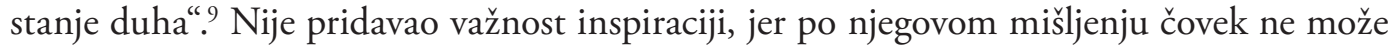
dati više nego što ima u sebi. Suštinu pisanja pronalazio je u tačnom izražavanju onoga što se htelo reći, priznajući da to nije nimalo lako. Delio je mišljenje da je pisanje književnog dela napor i da mora da bude napor.

Pravom varijantom Desnica ne smatra onu koja je „stilski najljepša“ i „formalno najdotjeranija“, već onu koja je bliža „onome što smo imali u glavi“ “. ${ }^{10}$ Da bismo u potpunosti mogli izraziti ono što nosimo u sebi, moramo imati dovoljno jasno osećanje i mišljenje o onome što želimo izraziti, odnosno moramo imati jasno doživljen sadržaj koji se ispoljava kroz adekvatan književni izraz.

6 „(...) dok djelo nije završeno, dok po mom mišljenju nije potpuno definitivnu formu dobilo, dok nije dano u štampu, neprestano se navraćam, pa makar bilo za svakog drugog, za svačije tuđe oči, završeno, kod mene leži u ladici mjesecima, godinama i za mene još nije završeno i neprestano ga iznova uzimam u rad.“

Jevto Milović, „Razgovor s Vladanom Desnicom o umjetničkom stvaranju“, Hotimično iskustvo: diskurzivna proza Vladana Desnice. Knjiga druga (prir. Dušan Marinković), Zagreb 2006., 117.

7 Vladan Desnica, „Prvu novelu namenio sam Politici“, Hotimično iskustvo. Knjiga druga, 105.

8 Jevto Milović, „Razgovor s Vladanom Desnicom o umjetničkom stvaranju“, 119.

9 Vladan Desnica, „Zapisi o umjetnosti“, Eseji, kritike, pogledi (= Sabrana djela Vladana Desnice, knj. IV), Zagreb 1975., 58.

10 „U tome i jest teškoća našeg izbora i izvor našeg dugog kolebanja: lako je razabrati što je 'objektivno uspjelije', 'koja je varijanta ljepša'; ali procijeniti koja je bliža 'onome što smo imali u glavi', često je neobično teško." V. DeSNicA, „Zapisi o umjetnosti“", Eseji, kritike, pogledi, 60. 
Desnica je naglašavao da je još kao početnik imao pri pisanju veoma jasnu sliku onoga što je želeo da postigne, „kao neki praobrazac koji lebdi u oblacima“ i koji je morao da fiksira na papir „kao neki model već budućeg djela“. Piščevo „odnošenje prema ekspresiji“"11 je beskompromisno. Smatrao je da „za sadržaj koji želimo uobličiti postoji negdje pod suncem jedan izraz - jedan jedini i nezamjenjivi, onaj pravi, idealni izraz" ${ }^{12}$

Većinu sopstvenih poetičkih stavova Desnica je iznio u svom eseju „Zapisi o umjetnosti“, objavljenom u Zagrebu 1952. godine u časopisu Krugovi. Mladi hrvatski pisci pomenute godine pokrenuli su časopis sa ciljem da se tadašnja izolovana sredina upozna sa novim tokovima evropske književnosti. Oko ovog eseja podignuta je velika buka u krugovima tadašnjih književnih kritičara (zagovornika socijalističke estetike), kao i anonimnih komentatora jer se Desničin doživljaj umetnosti nije uklapao u tadašnju normativnu estetiku.

Posmatrajući književna ostvarenja Vladana Desnice u kontekstu pokreta socijalne književnosti koji obuhvata period između dva svetska rata do 1950. godine, uočavamo izvesne razlike. U odnosu na zahteve pomenutog literarnog pokreta, koji je od pisca očekivao da zauzme određeni ideološko-društveni stav prema socijalnim pitanjima koja prikazuje u svojim delima, Vladan Desnica je u svom prvom romanu Zimsko ljetovanje (1950), kao i pripovetkama nastalim u tom periodu, analizirao i na sasvim nov način predstavio temu rata i revolucije. Književna kritika toga vremena zanemarivala je estetsku vrednost književnog dela ističući u prvi plan njegovu idejnu i političku određenost. Od pisaca se očekivalo da u svojim delima izražavaju političke poruke i verno prikazuju stvarnost, odnosno revoluciju.

Međutim, Desničin roman Zimsko ljetovanje (1950) donio je nove umetničke vrednosti među književnim ostvarenjima nakon Drugog svetskog rata. Ovim romanom pisac je učinio pomak u odnosu na socijalno angažovani roman, ističući u prvi plan čoveka i njegov doživljaj ratne stvarnosti. Prikazujući unutrašnju dramu svojih junaka u pomenutom romanu, Desnica se sve više udaljavao od poetike realizma i kretao ka psihološki produbljenom realističkom postupku. Navedenu poetsku intenciju pisac je posebno obrazložio u pomenutom eseju „Zapisi o umjetnosti“.

U težnji da u prvi plan istakne i prikaže čoveka u njegovoj različitosti, Desnica se založio za iskrenost kao jedan od glavnih poetičkih principa svakog umetničkog dela. Otkrivajući već u svojim prvim proznim ostvarenjima najrazličitije istine o čoveku, Desnica se nije uklapao u okvire tadašnje vladajuće ideologije. Svoj način stvaranja umetničkog dela Desnica je najslikovitije prikazao opisujući jednu od svojih junakinja u romanu Zimsko ljetovanje:

Pričala je dugo, ulazeći, kao i obično, u beskrajne potankosti, upadajući sama sebi u riječ, ili prekidajući nit da bi kratko nagovjestila nešto o čemu će kasnije govoriti... gorjela je od poštenog nastojanja da iz sebe istrese sve, da ništa ne ostane pri njoj, strahujući da ne bi ispustila koju pojedinost, jer bi je to peklo kao neka utaja ili iznevjereni zavjet. Zato se u govoru napinjala unoseći u nju svoju dušu. ${ }^{13}$

$\overline{11}$ „Takvo odnošenje prema ekspresiji potječe od polusvjesnog ali vrlo određenog osjećaja (koji se s vremenom sve više razvija, izoštrava i utanačava, dok se na koncu ne izvrgne u našeg nesnosnog tiranina, često mrskog neprijatelja)."V. Desnica, „Zapisi o umjetnosti“, Eseji, kritike, pogledi, 60.

12 Isto, 63.

13 Vladan Desnica, Zimsko ljetovanje, Zagreb 1950., 54. 
Desnica je nastojao da u svojim teorijskim stavovima i njihovoj primeni u literarnim ostvarenjima prikaže čoveka, život i svet u totalitetu. Prema njegovom mišljenju svi procesi traju in continuo, i u sferi realnog, i u sferi irealnog. Dvojnost je doživljavao kao „jedan od temeljnih zakona ljudske prirode“, bez koje se ne može integralno predstaviti nijedna ljudska ličnost. Pomenutu dvojnost možemo shvatiti i objasniti ukoliko poznajemo Desničinu celokupnu stvaralačku koncepciju. U njegovim delima, jedna pored druge stoje „suprotne istine ${ }^{\text {"14 }}$ koje pisac na jednoj višoj razini posmatranja spaja u celinu.

Sopstvenu viziju sveta Desnica je temeljio na shvatanju da je polarnost osnovna crta svega. Polarnosti kao što su biće - nebiće, večnost - prolaznost, beskonačno - konačno itd. smenjuju se u svom delovanju, i od te igre naizmeničnosti sastoji se život. ${ }^{15}$

Cilj svekolikog saznanja čovekova je da otkrije i prikaže te suprotnosti u celini, a ne samo jednu njihovu stranu. Po Desničinom mišljenju suprotnosti imaju podjednak značaj, pa čak suprotnosti bitnog i nebitnog: „Bitno predstavlja samo polovinu stvari. Često onu manje bitnu polovinu. Tek bitno i nebitno zajedno daju čitavu istinu. ${ }^{\text {"16 }} \mathrm{Na}$ osnovu navedenog mišljenja uočavamo da je Desnica dijalektičar, zagovornik shvatanja o jedinstvu suprotnosti.

U Desničinom načinu pevanja i mišljenja vidljive su dve značajne teorijske komponente: istinitost i uverljivost. Umetnost je, po njegovim rečima, ,jedino područje ljudske djelatnosti gdje je nemoguća laž: čim laž proviri, istim časom, automatski prestaje umjetnost“. ${ }^{17}$ Ključni elemenat realnosti za njega je istinitost, jer je realnost ${ }^{18}$ sama po sebi istinita, tako da ona nema potrebe da izgleda uverljivo. Nasuprot njoj, umetnost živi od uverljivosti. Cilj umetnosti je da preko uverljivosti stigne do istinitosti. Time bi se ukinula granica između realnog sveta i sveta umetnosti i stvorila jedna nova transponovana stvarnost čija će osnovna osobina biti uverljivost.

Osoben je i jedinstven Desničin doživljaj poetskog. Pod poetskim nije mislio na poetično, već je izrazom "poetsko i poezija“ označavao svaku pravu estetsku umetničku vrednost. Svi elementi umetničkog dela moraju biti poetski funkcionalni, a to ne znači da svaka misao likova iz romana mora biti lišena objektivnosti, već prevashodno mora da ovaploćuje jedan ljudski lik, ili ostvaruje jednu ljudsku situaciju, tj. da „služi poetskoj intenciji djela“. ${ }^{19}$

$\overline{14}$ „(...) svi mi jako volimo sebe, svi smo mi silno zaljubljeni u sve što je naše, svi mi stalno želimo da budemo 'mi'. Ali, isto tako strasno želimo i da budemo 'drugi' (...) I te dvije suprotne istine uporedo žive i djeluju u nama, kao i tolike druge suprotne istine. (...) Čini mi se da je to naprosto jedan repić težnje za univerzalnošću." Vladan Desnica, Proljeća Ivana Galeba, Zagreb 1975., 151.

15 „Svoju temeljnu i vrhunsku ontološku misao o svetu izrazio je u formi antinomije - ta misao nalazi se na kraju romana 'Proljeća Ivana Galeba' i izražava poslednje što čovek može da kaže o svetu na kraju svog životnog puta: 'I u stvarima je jedna luda zbrka i jedna mudra harmonija; jedan pijani besporedak i jedan dublji smisao. Kome je dano da to spozna, dobro je proživio svoj vijek. Taj je obišao čitav svoj krug." 'Milivoje Petrović, „Filozofske ideje u književnom delu Vladana Desnice“, Stvaranje, 22/1967., br. 7/8, 868-871.

16 V. Desnica, Proljeća Ivana Galeba, 265.

17 Vladan Desnica, Progutane polemike (prir. Jovan Radulović), Beograd 2001., 20.

18 „Realnost nema savršeno nikakve potrebe da izgleda uvjerljiva: ona ima iza sebe mnogo jače - istinitost. Umjetnost, naprotiv, čitava živi od uvjerljivosti. "Kao ilustraciju za navedeni teoretski postulat Desnica navodi sljedeći primjer: „U životu neko može težiti $120 \mathrm{~kg}$, imati dvostruki podvoljak i epske brčine i govoriti u basu - a pri tome se zvati Ive Kliskić. Umjetnost ne može sebi dozvoliti taj luksuz (...)“V. DesnicA, „Zapisi o umjetnosti“, Eseji, kritike, pogledi, 54.

19 „Jedna te ista misaona, esejistička i slična materija može u romanu ili drami imati znatnu, uprav nikakvu vrijednost, već prema tome da li ona ovaploćuje jedan ljudski lik, ostvaruje jednu ljudsku situaciju, da li dobro ili loše služi poetskoj intenciji djela.“ Vladan DesnicA, „Na temu: delo i kritika“, Hotimično iskustvo: diskurzivna proza Vladana Desnice. Knjiga prva (prir. Dušan Marinković), Zagreb 2005., 166. 
Kao zamenu za pojam poetsko i poetske vrednosti, Desnica je koristio pojam estetsko i estetske vrednosti. Umetničko delo, po njegovom mišljenju, vredi onoliko koliko poetskog ima u sebi. U navedenom stavu vidljiv je uticaj Kročeove estetike, koja poistovjećuje umetničko i poetsko. U tome i leži posebnost Desničinog realizma, koji sliku obuhvata u potpunosti, njenu spoljašnjost i njenu unutrašnjost. Desničin realizam, se zasniva na sveobuhvatnosti, njemu je cilj prikazati sve u potpunosti, sve što se vidi, oseća, misli, autentično i bez ulepšavanja, onako kako jeste.

U Desničinom poimanju književnosti uočavamo spoj estetike, etike i antropologije te i andrićevskog mišljenja da književnost ne služi ničemu ako ne služi čoveku i čovečanstvu. Posmatrajući književnost u celini, Desnica kao centralnu tačku izdvaja stvaralački subjekat jer je njegova egzistencija višestruka. On egzistira i kao stvaralac, i kao mislilac, i kao kritičar. Na sličan način egzistirao je i sam Desnica.

Čovjek-pojedinac je središnja kategorija u Desničinom sistemu mišljenja, a ideja o patnji najprisutnija u piščevoj stvaralačkoj viziji. Sve o čemu je razmišljao i pisao, posmatrao je kao zagovornik humanističke filozofije. Za njega je umetnik pre svega i iznad svega čovek. ${ }^{20}$ Bez velikog čoveka, prema mišljenju Vladana Desnice, nema ni velikog dela, ni velike umetnosti. Ideje na koje nailazimo čitajući Desničina dela možemo pronaći u modernim antropološko-filozofskim pravcima. Naime, savremena filozofija uglavnom se zasniva na antropološki zasnovanim teorijama, tj. na proučavanju čoveka i njegovih suštinskih problema. Glavni problem se ne nalazi ni u prirodi, ni u Bogu, ni u spoznaji, već u čoveku i najrazličitijim manifestacijama njegove egzistencije.

Desničin čovek prikazan je u određenim životnim okolnostima, u određenoj sredini u kojoj obitava provodeći svoj život. Nasuprot realnom svetu koji ga okružuje, Desnica je istovremeno predstavljao i čovekov unutrašnji svet, koji je odraz životne stvarnosti.

Prikazujući čovekov unutrašnji svet, Desnica je mnoge odgovore pronalazio u prirodi koja preslikava svoje osobine na čoveka i njegov doživljaj. Priroda je neizostavni tvorbeni elemenat umetničkih slika koje je Desnica stvarao u svojim pripovetkama i romanima. Želeći da smanji udaljenost između čovekovog unutrašnjeg sveta i stvarnosti koja ga okružuje, pisac je uvodio prirodu kao medijum koji ih povezuje.

Veza između čoveka i prirode u Desničinim prozama data je kao neminovnost i predodređenost koju čovek stiče rođenjem u određenom prirodnom okruženju koje se preslikava na njegovu unutrašnjost. Čovek i priroda predstavljaju jednu od binarnih opozicija iz kojih pisac gradi svoj umetnički svet.

Baveći se izučavanjem socijalne fenomenologije dalmatinskog zaleđa, Desnica nam je pored prikaza psiho-socijalne slike svoga zavičaja opisao i njegov živalj. U stvaralačkoj koncepciji Vladana Desnica priroda je tesno povezana sa čovekom, odnosno određeno geografsko područje sa ljudima koji na njemu obitavaju:

20 „Ja sam čovjek. Tako, naprosto čovjek. Čovjek po zanimanju. Iz pasije, ako hoćete." V. DesnicA, Proljeća Ivana Galeba, 303. 


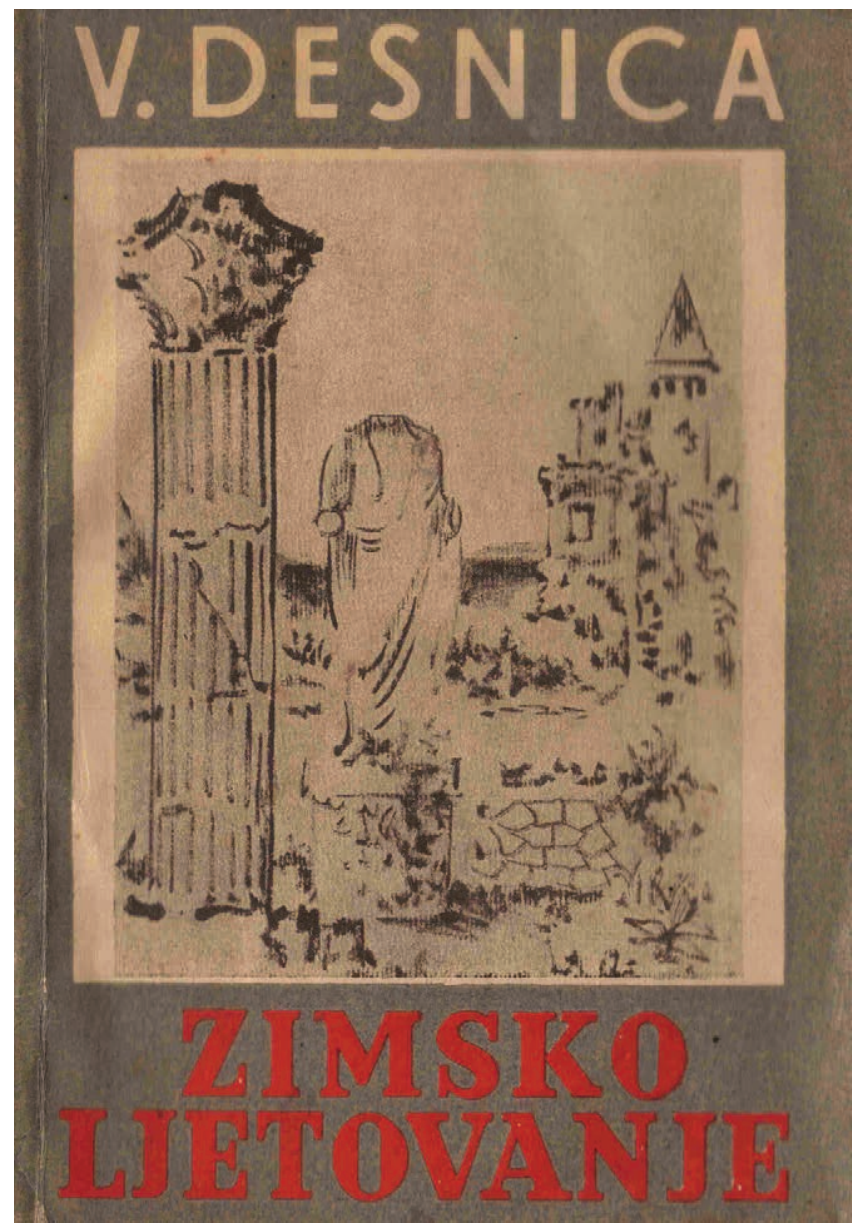

Sl. 1. Naslovnica prvog izdanja Desničina romana Zimsko ljetovanje (Zora, Zagreb 1950.)

Čovjek i pejzaž nigdje, ni u jednog našeg pisca, nisu tako sudbinski vezani kao u Desnice. Ta je veza prokletstvo, ali prokletstvo u stvarnom postojanju, u oporosti i tvrdoći života i muke na kamenu i pod vedrim nebom. ${ }^{21}$

Desničin čovek se nalazi u senzitivnom dodiru sa spoljašnjim svetom, njegova veza sa prirodom je čulna i neposredna. Doživljena kroz svest čovekovu, priroda je dobila istaknuto mesto u Desničinom delu. Zemlja, kao majka i hraniteljica, svoje osobine prenosi na čoveka. Tako skopčani u zajedničkom suživotu, zemlja i čovek postaju jedno. Iznedrivši se iz određenog prirodnog okruženja, čovekov duševni sklop biva neminovno njime uslovljen. Razvijajući se u okvirima prirode koja ga okružuje, čovek postaje njen odraz. Prikazati čoveka u različitim stanjima i okolnostima, glavni je stvaralački zadatak ovog pisca. Prikazujući u svom prvom romanu Zimsko ljetovanje čoveka koji se našao u dotad nepoznatim ratnim okolnostima, Desnica je u svojoj prvoj zbirci pripovedaka Olupine na suncu

21 Stanko Korać, „Književna saradnja Vladana Desnice u Magazinu Sjeverna Dalmacija“, Književna reč, 14/1985., br. 263, 26. 
smestio i analizirao čoveka u različitim okruženjima, posmatrajući prevashodno njegove unutrašnje doživljaje.

U Zimskom ljetovanju čovek se grčevito bori za život u vihoru rata, tražeći bilo kakvo sklonište da se spasi od smrti. Ta borba za goli život polako jenjava u Olupinama na suncu, u kojima Desničini junaci polako posustaju. Lica o kojima se govori u većini pripovedaka ove zbirke dotrajavaju svoje živote, izmučeni i umorni od mnogih životnih tegoba. Složenu problematiku čovekovog života Desnica je oslikavao kroz postupke i razmišljanja svojih junaka. Iako oni pripadaju različitim društvenim slojevima i profesijama, sve ih obuzima tišina i obamrlost nakon različitih životnih iskustava. Osnovu svake Desničine pripovetke, pored prikaza atmosfere, prostora i ugođaja, čini čovek zatečen u datoj situaciji koja najčešće određuje njegovu egzistenciju ili životni put. Desnica je pažljivo posmatrao svoje junake, ispitivao njihove postupke i motivaciju za određene psihičke reakcije.

Desničina umetnička proza pokazuje sklonost autora ka psihologiziranju. Iako su njegova prva prozna ostvarenja određena kao proze regionalnog karaktera (Zimsko ljetovanje i Olupine na suncu) u kojima pisac opisuje svoj zavičaj i njegovu okolinu, uočava se izrazita intencija za prikazivanje čoveka i njegovog unutrašnjeg sveta. Mnoge pripovetke ovog pisca nastale u kasnijem periodu, kao i najveći delovi romana Proljeća Ivana Galeba, predstavljaju prave psihološke analize, u čijem središtu se nalazi čovek i njegov unutrašnji svet.

Sagledavajući u hronološkom nizu umetničku prozu Vladana Desnice, uočavamo razvojni luk kojim se kretala njegova stvaralačka misao, polazeći od poetike realizma, koja se vremenom potiskuje dajući prednost psihološkim analizama junaka. Iako pripadaju različitim društvenim grupama i različitoj starosnoj dobi, Desničini junaci su ispunjeni patnjom i strahom od smrti.

Prikazujući živote svojih junaka, njihova psihička stanja i raspoloženja, pisac kroz raznolikost životnih sudbina izlaže svoje ideje i poetičke stavove. Iako prikazuje različita ljudska stradanja, njegove proze ne odišu patetikom i piščevim sažaljenjem nad junacima. Suočavajući se svakodnevno sa svojim životom, Desničini junaci su duboko svesni svojih grešaka i životne promašenosti. Posmatrajući u celosti zbirke njegovih pripovedaka, uočavamo njihovu zajedničku osobenost: događaj, kao tvorbeni elemenat svake priče, biva samo polazište u piščevom razmatranju čoveka i njegovih karakternih osobina. Najmanje prostora u Desničinim prozama zauzima sam događaj, dok je najviše pažnje posvećeno čoveku i stvaranju njegovog unutrašnjeg portreta.

Junaci koje susrećemo u prvoj i drugoj zbirci Desničinih pripovedaka, Olupine na suncu (1952) i Proljeće u Badrovcu (1955), predstavnici su različitih životnih sredina (gradske i seoske), kao i različitih ljudskih karaktera. Polarizacija između sela i grada, prisutna već u Desničinom prvom romanu Zimsko ljetovanje, izražena je u umetničkoj prozi ovog pisca sve do pojave njegove treće zbirke pripovedaka Tu, odmah pored nas (1956). U njoj je pisac napustio regionalne motive, bivajući sve više zaokupljen intelektualnim i psihološkim problemima čoveka u savremenom društvu. Oslobođene regionalne pripadnosti i svedene na prikazivanje čovekovog unutrašnjeg života, pripovetke ove zbirke predstavljaju nagoveštaj romana Proljeća Ivana Galeba. 
Svojom trećom zbirkom Desnica je ostvario metodski i tematski preokret u svom opusu, ističući u prvi plan čoveka i njegov konkretni problem. U težnji da što šire obuhvati čovekovu patnju, pisac je oslikao različite situacije u kojima se može zadesiti čovek na svom životnom putu.

Poetički stavovi koje je Vladana Desnice izložio u svojim pripovetkama ukazuju da je pisac najveću pažnju poklanjao čoveku i njegovom unutrašnjem doživljaju. Stvarajući lik Ivana Galeba i prikazujući njegov životni put, Vladan Desnica je ostvario sintezu svojih poetičkih stavova. Galebova razmišljanja o knjigama, o stvaranju modernog romana koji bi prevazilazio sve postojeće žanrove, ukazuju na piščevu težnju za novim literarnim postupkom, koji ostvaruje upravo stvaranjem ovog romana. Iznoseći novu poetiku romana, Desničin junak odbacuje spoljašnje događaje i fabulu kao primarne elemente romaneskne strukture.

Gradeći Galebov umetnički lik, pisac je iznio svoje stavove o umetnosti, svoj doživljaj vremena, kao i svoja temeljna stvaralačka opredeljenja. U težnji da bar na trenutak zaustavi proteklo vreme, Galeb piše dnevnik da bi sačuvao nešto od svog proteklog života.

Analizirajući sopstveni život, Desničin junak razmišlja o suštini ljudske egzistencije, kao i neminovnom završetku čovekovog života. Prema Galebovom mišljenju, osnovni zadatak svakog čoveka je u tome da traga za smislom života i u tom traganju da pronađe puteve sopstvenih želja i mogućnosti.

U traženju svojih puteva Galeb je došao do zaključka da je čovek prevashodno određen samim nasleđem. Galebova porodična linija potvrđuje značaj naslednih faktora u razvoju čovekove ličnosti. Nasleđe se ukazuje kao neminovnost, kao prirodna sila koja utiče na čoveka i njegovu sudbinu. Galeb je nasledio istančanu krv i time bio predodređen da bude umetnik. Upravo tom činjenicom pisac ukazuje na raspolućenost između spoljašnjeg i unutrašnjeg čovekovog sveta. U težnji da što bolje sagleda i izrazi čovekov unutrašnji svet, pisac je stavio stvarnost u drugi plan, posmatrajući je kao polazište čovekovih doživljaja i osećanja.

Gradeći Galebov unutrašnji svet, Desnica je pošao od perioda detinjstva u kom se formiraju najznačajnije čovekove osobine. Detinjstvo je, u stvaralačkoj poetici ovog pisca, najsvetliji period čovekovog života, ispunjen beskrajem i odsustvom svesti o smrti. Smrt se u Desničinoj stvaralačkoj poetici i Galebovom doživljaju javlja kao neminovnost, kao jedina i konačna istina sa kojom se svaki čovek suočava.

Nasuprot motivu smrti Vladan Desnica je postavio motiv proleća, koji označava sve lepe trenutke u životu Ivana Galeba. Upravo u toj igri naizmeničnosti proleća i smrti, lepih i ružnih trenutaka Galebovog života, pisac je posvetio najviše mesta u ovom romanu. U težnji da pobedi smrt, Desničin junak utehu pronalazi u umetnosti, u stvaranju kao jedinom načinu da se odupre neminovnom kraju. Umetnost u stvaralačkoj poetici ovog pisca predstavlja igru koja povezuje proleća i smrt, jedan od načina čovekove borbe da se odupre sopstvenoj prolaznosti.

Boreći se da što lakše provede svoje bolničke dane, Galeb utehu pronalazi u svetlosti, u sunčanom danu, u suncu kao negaciji smrti i izvoru života. Svetlost se u Desničinoj poetici pojavljuje i kao stvaralački princip koji je neophodan u stvaranju umetničkog dela. Galebova razmišljanja o umetnosti i stvaranju umetničkih dela koja su prisutna u čitavom romanu, daju ukupnu sliku stvaralačke poetike ovog pisca. 
Iznoseći život umetnika Ivana Galeba i njegov doživljaj umetnosti, Desnica je potvrdio svoj poetski stav da je umetnost dvostruki proces, prikazivanje pojedinačnog života preko kojeg se može sagledati ono što je opšte i univerzalno u svakog čoveka. Prikazujući Galeba kao umetnika koji je svoj život proveo u potpunoj posvećenosti svojoj umetnosti, Desnica je ostvario sliku svakog umetnika koji je predan i odan svojoj umetnosti.

Stvaranje Galebovog stvaralačkog portreta, kao i celokupnog Desničinog opusa zasniva se na isticanju dva najznačajnija motiva: prvi je motiv smrti, koji je neprestano prisutan u Galebovim razmišljanjima kao i kod svih ostalih Desničinih junaka, dok je drugi motiv isticanje junakovog „ja“, koje je jedinstveno i neponovljivo. Upravo je čovekova svest o nemogućnosti nadoknade sopstvenog ,ja“ prouzrokovala neprestani strah od smrti. Da bi sačuvao sopstveno „ja“, Desničin junak Ivan Galeb poručuje „da treba biti ono što jesi“. Ostvarujući navedeni princip u sopstvenom životu, čovek pronalazi smisao i opravdanje svog postojanja.

Autentičnost i neponovljivost umetnikove ličnosti uslov je da se stvori autentično i neponovljivo umetničko delo. U težnji da stvori jedinstveno umetničko delo, Vladan Desnica je svoje junake, uključujući i Ivana Galeba, istovremeno sprovodio kroz nepregledne prostore realnog i irealnog sveta, želeći da prikaže podvojenost čoveka i sveta.

Analizirajući neprestano svoj unutrašnji svet i doživljaje koji ga prate, Ivan Galeb dolazi do zaključka da je stvarnost prevashodno ono što se čoveku dogodi u životu, kao i njegova svest o tome. Ostvarujući istovremeno prikazivanje događaja koji su obeležili Galebov život, kao i njegovih osećanja, Desnica je potvrdio snagu i inovativnost svog stvaralačkog postupka.

Našavši se na samom kraju svog životnog puta, Ivan Galeb smisao i značaj života pronalazi u malim stvarima, u prirodi i slobodi, u želji da pomogne onima kojima je pomoć potrebna. Zahvaljujući takvom stavu prema životu, Galeb ostavlja humanističku poruku da je osnovni zadatak svakog pojedinca da prevashodno bude i ostane čovek.

Težnja za slikanjem neispravljene i nepročišćene realnosti, koja je deo čovekovog unutrašnjeg sveta, glavni je razlog zbog kojeg su stranice Desničinih proznih dela tako žive i stvarne. Sve što prikazuju, doživljeno je i shvaćeno u vizuri pisca koji poseduje stvaralačku mogućnost da pronađe adekvatan izraz za svoj poetski doživljaj. Poetski doživljaji Vladana Desnice duboko su proživljeni, promišljeni, osećani. Sve što je napisano njegovom rukom poseduje osobenu sugestivnost i uverljivost. Ni u jednom momentu ne ostavlja nedorečenu svoju misao, već brani i obrazlaže sopstveni stav, uveravajući čitaoca u ispravnost svog mišljenja. Neizmerljivo je velika sugestivna moć svake Desničine reči. 


\section{$\cos$ \\ The Poetics of Vladan Desnica’s Artistic Prose}

When examining Desnica's literary output as a whole, one can note that it is free of any certain literary mode of expression, literary movement or style. Desnica's viewpoints on his poetics explained in essays, theoretical texts, stories and novels, surpass various affiliations (ideological, political, social or generational) that might shackle the author's personality. While creating his works, this writer was primarily focused on creating an aesthetic value of the literary work, which according to him, was the primary artistic value. In an attempt to distinguish man in all his diversity, Desnica looks to honesty as one of the main poetic principles in any work of art. By revealing in his first prose various truths about man, he did not fit into the frame of contemporary ideologies. By portraying man's inner world, he finds many answers in nature that maps its traits on man and his perception. Nature is an inevitable building element in artistic images that Desnica conjures in his stories and novels. Chronologically following this author's artistic prose, we may observe an arc along which his creative thought moved, starting from the poetics of realism which was suppressed over time, giving way to psychological analyses of the characters. Although they belong to various social and age groups, Desnica's characters are filled with suffering and a fear of death. In portraying the lives of his heroes, their psychic states and moods, the author expounds his own ideas and poetic attitudes in the diversity of their fates.

Keywords: Vladan Desnica, poetics, artistic prose, aesthetic value, experience, integral realism

\section{$\cos$}

\section{Literatura}

Vladan Desnica, Eseji, kritike, pogledi (= Sabrana djela Vladana Desnice, knj. IV), Zagreb 1975.

Vladan Desnica, Fratar sa zelenom bradom, Zagreb 1959.

Vladan Desnica, Hotimično iskustvo: diskurzivna proza Vladana Desnice. Knjiga druga (prir. Dušan Marinković), Zagreb 2005.

Vladan Desnica, Olupine na suncu, Zagreb 1952.

Vladan Desnica, Progutane polemike (prir. Jovan Radulović), Beograd 2001.

Vladan Desnica, Proljeća Ivana Galeba, Zagreb 1977.

Vladan Desnica, Proljeće u Badrovcu, Beograd 1955.

Vladan Desnica, Tu, odmah pored nas, Beograd 1956.

Vladan Desnica, Zimsko ljetovanje, Beograd 1993.

Radomir V. Ivanović, Po sunčanom satu, Novi Sad 2001.

Stanko Korać, „Književna saradnja Vladana Desnice u Magazinu Sjeverna Dalmacija“, Književna reč, 14/1985., br. 263, 26-28.

Jevto Milović, Razgovor sa umjetnicima, Beograd 1983.

Vojislav Nikčević, „Poetika Vladana Desnice“, Izraz, 13/1969., br. 7, 53-55.

Grozdana Olujıć, Pisci o sebi, Beograd 1959.

Vlatko Pavletić, Trenutak sadašnjosti, Zagreb 1960.

Milivoje Petrović, „Filozofske ideje u književnom delu Vladana Desnice“, Stvaranje, 22/1967., br. 7/8, 868-877.

Dušan Rapo, Novele i romani Vladana Desnice, Zagreb 1989. 